University of Nebraska - Lincoln

DigitalCommons@University of Nebraska - Lincoln

Publications, Agencies and Staff of the U.S.

Department of Commerce

U.S. Department of Commerce

4-2009

\title{
Movements and Dive Patterns of a Rehabilitated Risso's dolphin, Grampus griseus, in the Gulf of Mexico and Atlantic Ocean
}

\author{
Randall Wells \\ Center for Marine Mammal and Sea Turtle Research, Mote Marine Laboratory, 1600 Ken Thompson \\ Parkway, Sarasota, Florida \\ Charles Manire \\ Dolphin and Whale Hospital, Mote Marine Laboratory and Aquarium \\ Lynne Byrd \\ Dolphin and Whale Hospital, Mote Marine Laboratory and Aquarium \\ David Smith \\ Dolphin and Whale Hospital, Mote Marine Laboratory and Aquarium \\ Janet Gannon \\ Center for Marine Mammal and Sea Turtle Research, Mote Marine Laboratory \\ See next page for additional authors \\ Follow this and additional works at: https://digitalcommons.unl.edu/usdeptcommercepub \\ Part of the Environmental Sciences Commons
}

Wells, Randall; Manire, Charles; Byrd, Lynne; Smith, David; Gannon, Janet; Fauquier, Deborah; and Mullin, Keith, "Movements and Dive Patterns of a Rehabilitated Risso's dolphin, Grampus griseus, in the Gulf of Mexico and Atlantic Ocean" (2009). Publications, Agencies and Staff of the U.S. Department of Commerce. 26.

https://digitalcommons.unl.edu/usdeptcommercepub/26

This Article is brought to you for free and open access by the U.S. Department of Commerce at DigitalCommons@University of Nebraska - Lincoln. It has been accepted for inclusion in Publications, Agencies and Staff of the U.S. Department of Commerce by an authorized administrator of DigitalCommons@University of Nebraska - Lincoln. 


\section{Authors}

Randall Wells, Charles Manire, Lynne Byrd, David Smith, Janet Gannon, Deborah Fauquier, and Keith Mullin 
MARINE MAMMAL SCIENCE, 25(2): 420-429 (April 2009)

(C) 2009 by the Society for Marine Mammalogy

DOI: $10.1111 / \mathrm{j} .1748-7692.2008 .00251 . x$

\title{
Movements and dive patterns of a rehabilitated Risso's dolphin, Grampus griseus, in the Gulf of Mexico and Atlantic Ocean
}

\author{
RANDALL S. WELLS \\ Center for Marine Mammal and Sea Turtle Research, \\ Mote Marine Laboratory, \\ 1600 Ken Thompson Parkway, \\ Sarasota, Florida 34236, U.S.A. \\ E-mail: rwells@mote.org \\ Charles A. Manire \\ LYNNE BYRD \\ DAVID R. SMITH \\ Dolphin and Whale Hospital, \\ Mote Marine Laboratory and Aquarium, \\ 1600 Ken Thompson Parkway, \\ Sarasota, Florida 34236, U.S.A. \\ JANET G. GANNON \\ Deborah Fauquier \\ Center for Marine Mammal and Sea Turtle Research, \\ Mote Marine Laboratory, \\ 1600 Ken Thompson Parkway, \\ Sarasota, Florida 34236, U.S.A. \\ KeIth D. Mullin \\ NOAA National Marine Fisheries Service, \\ Southeast Fisheries Science Center, \\ Pascagoula, Mississippi 39568, U.S.A.
}

Risso's dolphins (Grampus griseus) occur throughout the world in tropical and temperate waters. The best estimates of abundance for Risso's dolphins are 1,589 $(\mathrm{CV}=0.27)$ for the northern Gulf of Mexico and 20,479 (CV $=0.59)$ for the U.S. Atlantic Ocean (Waring et al. 2006). G. griseus is the fourth most abundant cetacean species in the oceanic waters of the northern Gulf and is found in all seasons (Mullin et al. 1994, 2004; Maze-Foley and Mullin 2006).

Risso's dolphins typically can be found over the continental shelf edge and the upper continental slope, where sea surface temperatures exceed $10^{\circ} \mathrm{C}$ (Baumgartner 1997, Kruse et al. 1999). They frequent areas of high seafloor relief, where they may feed on mesopelagic and vertically migrating cephalopods (Norris and Dohl 1980, Clarke and Pascoe 1985, Clarke 1986), but no previous studies of diving behavior of Rissos's dolphins have been reported (Baird 2002). Their oceanic distribution limits opportunities for systematic study of movements and dive patterns. 


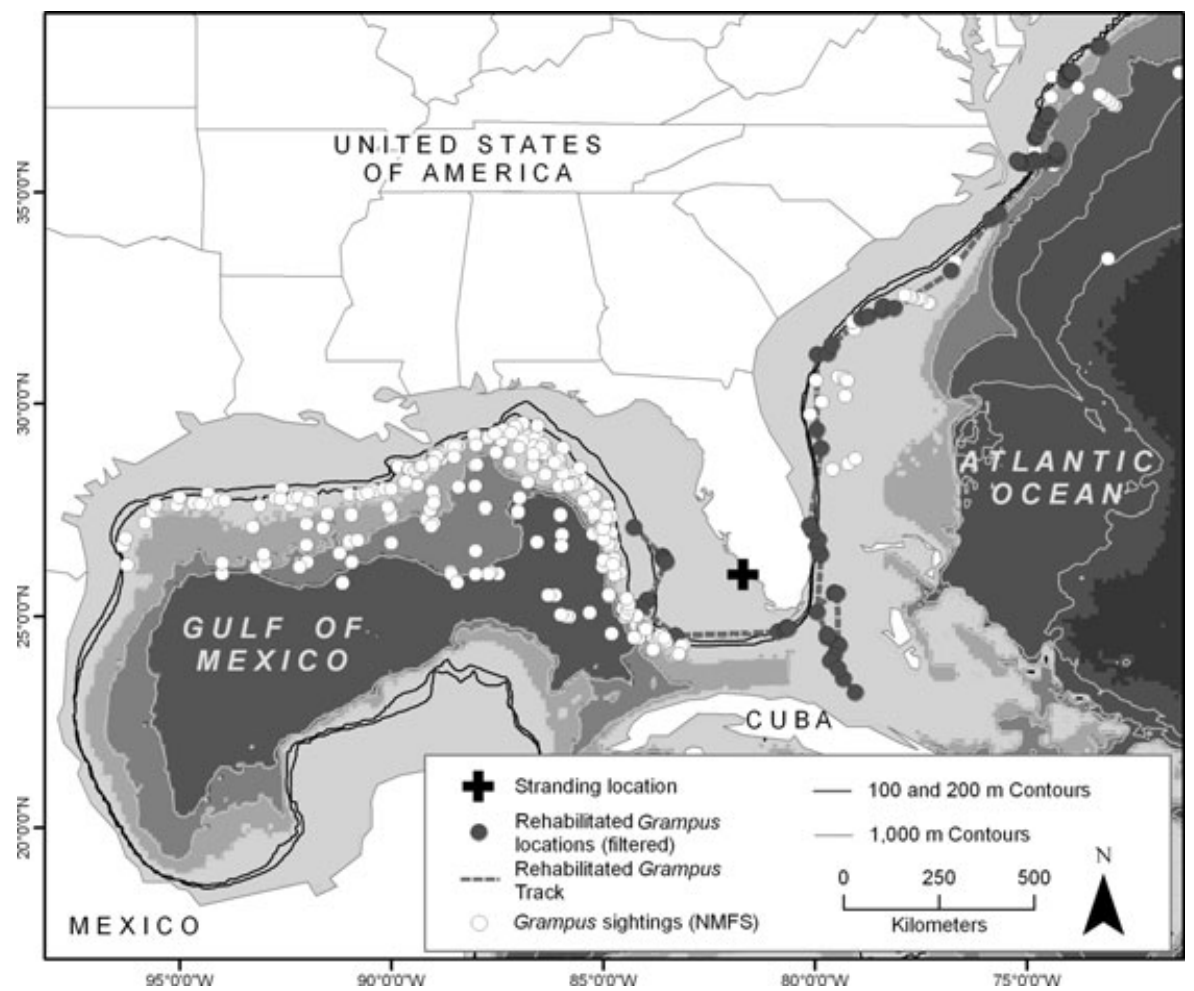

Figure 1. Stranding location on the southwest coast of Florida and filtered tracking locations for rehabilitated Risso's dolphin "Clyde” overlaid on locations of Risso's dolphin sightings from National Marine Fisheries Service aerial and shipboard cetacean surveys in the Gulf of Mexico during 1992-2004, and in the Atlantic Ocean during 1998, 1999, and 2002. Connecting lines between Clyde's positions approximate the track.

An opportunity to learn about the movements and dive patterns of a Risso's dolphin resulted from the rehabilitation, release, and follow-up monitoring of the sole surviving dolphin from a mass stranding of four adult males and one adult female on 16 July 2005 near Caxambas Pass, Marco Island, Florida (Fig. 1; $25.894^{\circ} \mathrm{N}$, $\left.82.707^{\circ} \mathrm{W}\right)$. Three of the males were euthanized or died on the stranding beach. The remaining adult male (MML 0514B, "Clyde"), along with the adult female, was admitted to Mote Marine Laboratory's dolphin hospital in Sarasota, Florida, with gastric ulcers, low serum phosphorus, low serum iron, low alkaline phosphatase, and elevated lactate dehydrogenase. At the time, the diagnosis was left open but in retrospect, it is likely that the dolphin had multiple internal abscesses. Clyde was treated with antiulcer medications immediately and with antibiotics and antifungals when his white blood cell count became elevated several days after admission. He began eating on the third day and continued to eat very well throughout rehabilitation, consuming up to $18 \mathrm{~kg}$ of squid daily. The male's gastric issues were resolved within $6 \mathrm{wk}$, but his white cell count continued to oscillate between elevated and normal 


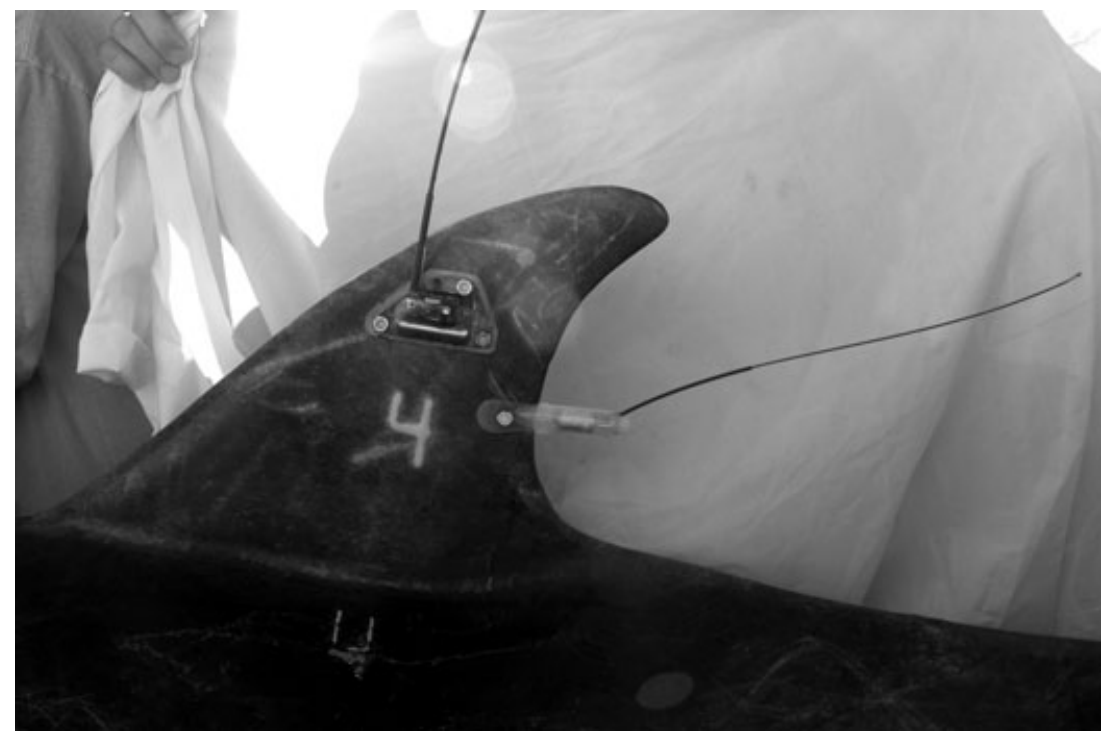

Figure 2. Marks and tags placed on Clyde for postrelease monitoring, including the 5-cmhigh freeze brand (" 4 " on center of fin and body below fin), Splash tag (top center of fin), and VHF "bullet tag" (trailing edge of fin).

levels for about 4 mo. All medications were discontinued, Clyde was freeze-branded (Wells 2002), and he was essentially ready for release in December 2005, but his release was delayed to allow for the female's recovery and release together. The female died on 3 February, leading to Clyde's release alone. Upon release, Clyde weighed $267 \mathrm{~kg}$ and measured $277 \mathrm{~cm}$.

Clyde was released at 1428 (EST) on 10 February 2006, about $159 \mathrm{~km}$ offshore of Sarasota $\left(27.092^{\circ} \mathrm{N}, 84.267^{\circ} \mathrm{W}\right)$. He was released when the vessel reached a water depth $(125 \mathrm{~m})$ and region near the continental shelf edge where Risso's dolphins were known to occur. Clyde was tagged en route to the release site with a satellite-linked Splash time-depth recording tag (Wildlife Computers, Redmond, WA). The Splash tag package $(8.0 \mathrm{~cm} \mathrm{~L} \times 4.5 \mathrm{~cm} \mathrm{H} \times 2.2 \mathrm{~cm} \mathrm{~W}, 70 \mathrm{~g} ; 20$-cm semirigid antenna) included a satellite transmitter (PTT: Cricket), controller board, pressure transducer, and single AA battery generating $0.5 \mathrm{~W}$ of radiated power and an estimated life of 25,000 transmissions. The tag was cast in epoxy and designed for water depths of up to $1,000 \mathrm{~m}$. The Splash tag, with closed-cell foam backing, was attached to the dorsal fin by three $0.64-\mathrm{cm}$ delrin pins, secured on the opposite side of the fin with padded washers and corrosible nuts (Fig. 2). In addition, a small VHF tag (Advanced Telemetry Systems, Inc., Isanti, MN; Model\# MM130) was also attached in an orthopedic plastic "bullet-tag" configuration (Fig. 2), for direct, line-of-sight radio tracking should the dolphin come within range of coastal tracking efforts. However, no opportunities for direct tracking occurred.

The Splash tag was programmed to transmit up to 250 times during an 8-h session each day (1000-1759 GMT). Data from the tag, plus Location Class (LC) information 
grading the quality of the locations, were provided by ARGOS (CLS America, Inc., Largo, MD). Plausible locations were identified through application of Argos_Filter V7.02 (Douglas 2006, Klatsky et al. 2007). The program identifies implausible locations based on two different filtering methods. The minimum-redundant-distance measure employs a user-defined distance as a threshold for determining redundant locations. The distance, angle, and rate measurement (DAR) attempts to remove implausible locations based on the fact that most suspicious ARGOS locations cause the animal to incorrectly move a substantial distance and then return, with the subsequent location being more correct (Douglas 2006). Using threshold filtering criteria of $20 \mathrm{~km} / \mathrm{h}$ as the maximum sustainable rate of travel, $15 \mathrm{~km}$ for maximum redundant distance, and including all positions with LC 2 or LC 3 (estimated error $<350 \mathrm{~m}$ ), $82 \%$ of the locations were considered plausible through DAR and were used for analyses.

Rates of travel were measured using filtered sequential locations separated by at least $1 \mathrm{~h}$. Filtered ARGOS positions were entered into a Geographic Information System and overlaid with bathymetry, slope, and sea surface temperature layers. Bathymetry was obtained from the "ETOPO" global 2-min resolution data set (Smith and Sandwell 1997). The ArcGIS extension "Gridspot" was used to extract rasterbased values for environmental variables at each location. Slope was derived from this bathymetry using ArcGIS Spatial Analyst by calculating the maximum rate of change from each raster cell to adjacent cells. Sea surface temperatures averaged over $8 \mathrm{~d}$ were obtained from MODIS Aqua thermal-far infrared bands (4-km resolution, http://poet.jpl.nasa.gov/).

The Splash tag was programmed to collect and archive dive data for four 6-h periods each day, set to local Eastern Standard Time: Dawn: 0300-0859; Day: 0900-1459; Dusk: 1500-2059; and Night: 2100-0259. A dive was defined as any submergence greater than $1 \mathrm{~m}$ to differentiate between actual dives and time spent at the surface; submergences to less than $1 \mathrm{~m}$ were not compiled. Dive data recorded during each 6-h period included (1) maximum depth of each dive, recorded as the numbers of dives within each of 14 programmed dive depth range categories (bins); (2) duration of each dive, recorded as the numbers of dives occurring within each of 14 programmed dive duration bins; and (3) time-at-depth, recorded as the amount of time spent within each of 14 programmed depth ranges. Data within dive depth and dive duration bins were analyzed as percentages of total occurrences across days. For analysis, the bin for the first $30 \mathrm{~s}$ of dive durations was excluded because these were often repeated surfacings associated with respirations between true dives and because this first bin was filled to capacity in $14 \%$ of dive records, yielding incomplete data and making this bin unusable (Wells et al. 2008). Time-at-depth was calculated as the average of percentages calculated for each 6-h block. Archived data were transmitted during the daily 8 -h transmission session.

Signals were received from the Splash tag over a period of $23 \mathrm{~d}$, between 10 February 2006 and 4 March 2006. Transmissions likely ceased prematurely because the Splash tag was shed. Battery voltage and current drawn were within expected ranges in the final status report provided by the tag. The progressive loss of specific data at different times suggests changes in the tag's ability to fully transmit 
messages (corruption of message tail ends), perhaps due to a decline in the amount of time that the tag was "dry" during surfacings. The longest messages, the dive data, dropped out first (24-26 February), followed by the intermediate-length tag status messages (28 February), and then location data, the shortest messages ( 4 March). It seems likely that one or more of the three attachment pins were released prematurely, leading to the progressive repositioning of the tag on the fin such that it was no longer "dry" for sufficient time for message transmission, and ultimately the tag was shed. It is possible that the tag attachments, designed as weak links for dolphin safety in case of entanglement, were not of sufficient strength to withstand the forces applied by a dolphin as large as Clyde (the largest we have tagged with this system) while engaged in the aerial or social behaviors typical for the species (Kruse et al. 1999) and performed by Clyde during rehabilitation.

Clyde traveled more than 3,300 km from the Gulf of Mexico to the Atlantic Ocean off Delaware (Fig. 1). Although Risso's dolphins in the Gulf and Atlantic are currently considered by the National Marine Fisheries Service (NMFS) to belong to separate putative stocks (Waring et al. 2006), there is no genetic information to confirm this distinction. ${ }^{1}$ Because Clyde is the first Risso's dolphin to be tracked in the Gulf, it is not possible to determine if his movements into the Atlantic are representative of the species, or if they reflect possible disorientation from rehabilitation and release without his schoolmates more than $330 \mathrm{~km}$ from his stranding site. It is not known if Clyde's stranding site was within his normal range. Much of his travel was with major current systems, including the Loop Current of the Gulf and the Gulf Stream. On average, Clyde traveled at $7.19 \mathrm{~km} / \mathrm{h}(\mathrm{SD}=3.81, n=58$, range $=0.6-18.5 \mathrm{~km} / \mathrm{h})$. Typical Risso's dolphin swimming speeds are 6-7 km/h (Kruse et al. 1999).

Clyde's use of habitats was mostly consistent with what is known for this species from surveys and observations in the Gulf and Atlantic (Waring et al. 2006). Figure 1 depicts Clyde's track relative to sighting locations of Risso's dolphins from NMFS aerial and shipboard cetacean surveys during 1992-2004 (Davis et al. 1998; Mullin et al. 1994, 2004; Mullin and Fulling 2004; Maze-Foley and Mullin 2006; Waring et al. 2006). The average water depth at Clyde's filtered locations was $548 \mathrm{~m}$ (SD = $599 \mathrm{~m}, n=76$, range $=3-2,300 \mathrm{~m})$ and the average slope was $1.17^{\circ}(\mathrm{SD}=1.41$, $n=76$, range $\left.=0.01-5.52^{\circ}\right)$. NMFS surveys have found Risso's dolphins in the Gulf over the steepest gradients, in water depths of 97-3,440 m (Fig. 1; Davis et al. 1998; Mullin et al. 1994, 2004; Maze-Foley and Mullin 2006). Baumgartner (1997) characterized Risso's dolphin core habitat in the northern Gulf as the steep sections of the upper continental slope, bounded by $350-\mathrm{m}$ and $975-\mathrm{m}$ isobaths, with an average slope of about $1.25^{\circ}$. The association with the shelf edge and upper continental slope is likely related to the fact that such regions often demonstrate increased biological activity from the formation of oceanic fronts along the shelf break, which can lead to prey aggregation. Clyde's final transmissions came from a region where Risso's dolphins have been seen frequently during summer NMFS surveys (Waring et al. 2006), and near where a rehabilitated juvenile male Risso's dolphin (Rocky) released

\footnotetext{
${ }^{1}$ Personal communication from P. Rosel, National Marine Fisheries Service, 646 Cajundome Boulevard, Lafayette, LA, 4 May 2007.
} 


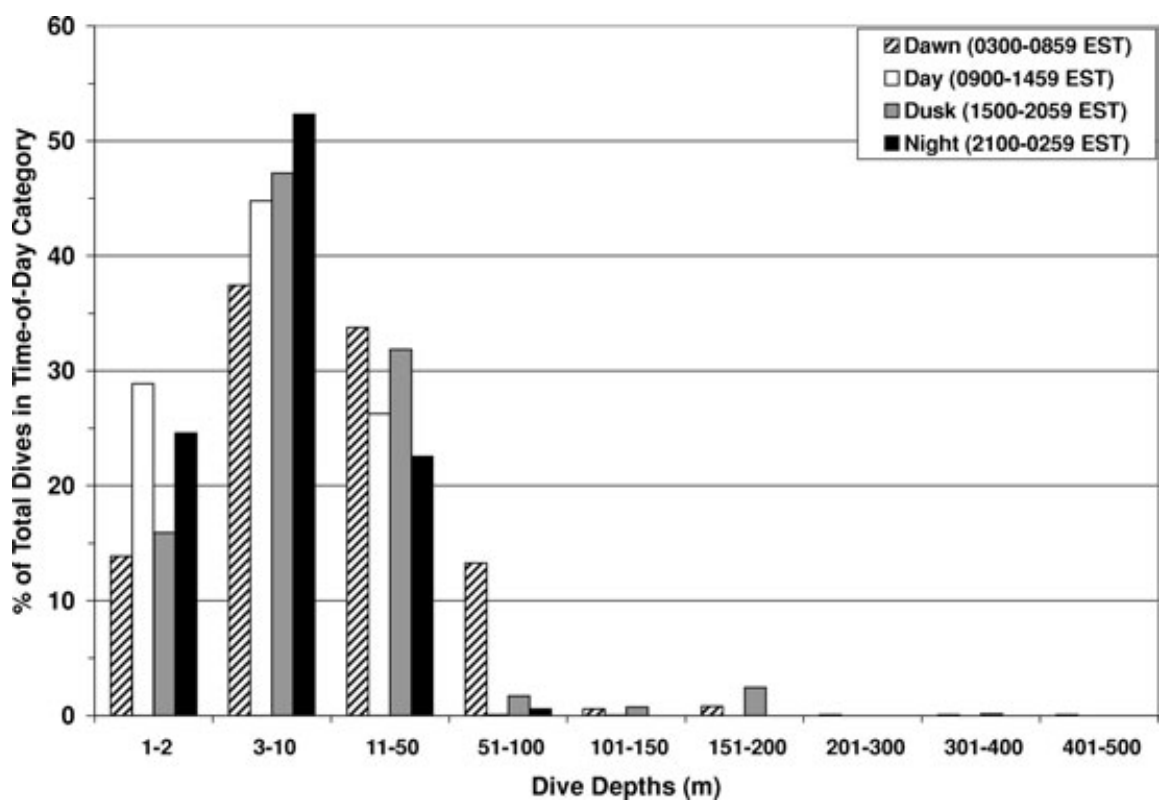

Figure 3. Dive depth profiles relative to time of day. Bars reflect percentages of all dives occurring within each of four specified time-of-day categories, calculated from all submergences to depths greater than $1 \mathrm{~m}$.

off Delaware by the Riverhead Foundation was tracked during 13 April-19 June 2005 (http://whale.wheelock.edu).

In addition to physiography, water temperature is an important dolphin habitat component. Risso's dolphins primarily occur where temperatures exceed $10^{\circ} \mathrm{C}$ and are most common in waters of $15-20^{\circ} \mathrm{C}$ (Kruse et al. 1999, Baird 2002). In the northern Gulf, Risso's dolphins are found in average sea surface temperatures of $24.4^{\circ} \mathrm{C}$ (range $19-29.5^{\circ} \mathrm{C}$, Davis et al. 1998). Clyde moved through a wide range of sea surface temperatures, averaging $19.2^{\circ} \mathrm{C}(\mathrm{SD}=5.8, n=47$, range $=10.0$ $25.3^{\circ} \mathrm{C}$ ). He was released into Gulf waters of about $22^{\circ} \mathrm{C}$. Temperatures warmed to about $25^{\circ} \mathrm{C}$ as he moved around the southern tip of Florida and then cooled to $10-11^{\circ} \mathrm{C}$ at the northernmost extent of his track.

Depth information was obtained from 6,048 dives that exceeded $1 \mathrm{~m}$. Clyde frequented the upper portion of the water column, with more than $95 \%$ of his dives occurring within $50 \mathrm{~m}$ of the surface (Fig. 3). Only $0.09 \%$ of dives were to depths below $200 \mathrm{~m}$, with the deepest being a single dive to 400-500 m on 18 February, when Clyde was north of Cuba. Such unusually deep dives may have been in search of the neritic, oceanic, and sometimes bottom-dwelling cephalopods on which Risso's dolphins feed (Clarke 1986). More dives below 50 m occurred during Dawn and Dusk, suggesting a possible crepuscular pattern for deeper diving (Fig. 3).

Dive duration data were obtained for 2,245 dives that exceeded $30 \mathrm{~s}$ (Fig. 4). More than $99 \%$ of dives lasted less than $6 \mathrm{~min}$, with 2- to 4 -min dives being most 


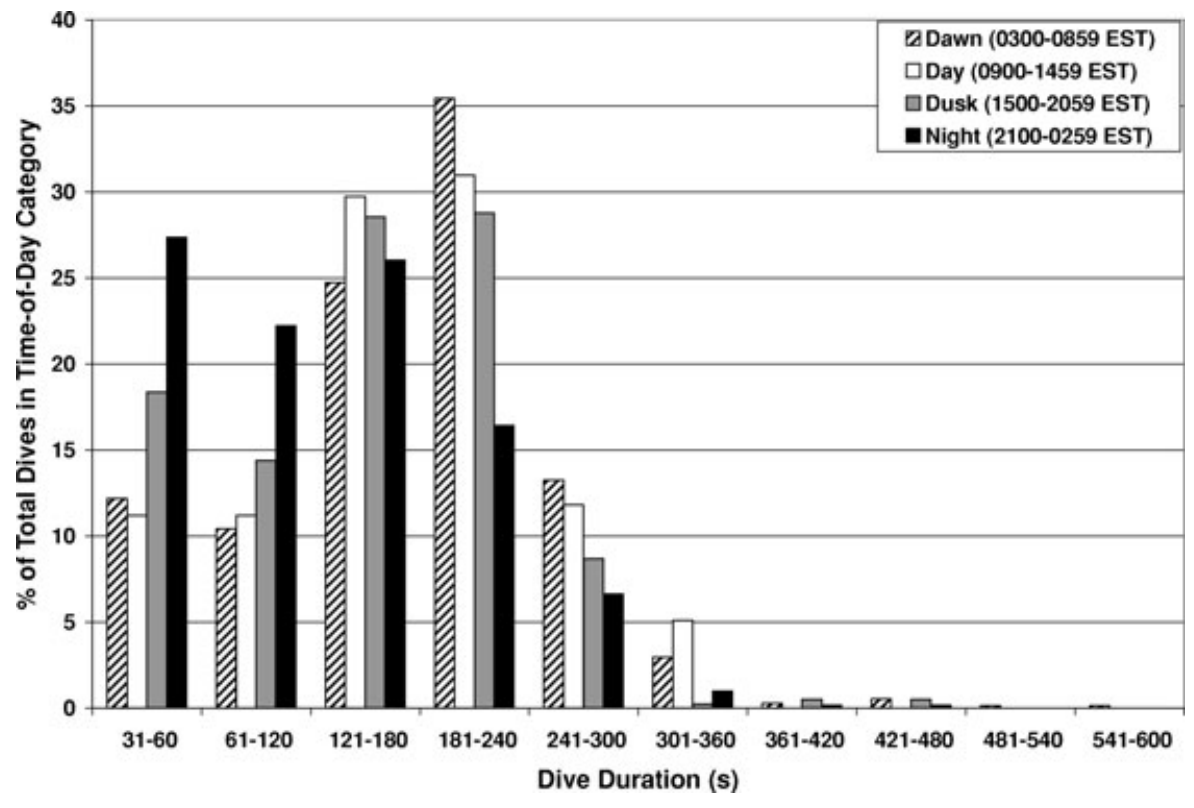

Figure 4. Dive duration profiles relative to time of day. Bars reflect percentages of all dives occurring within each of four specified time-of-day categories, calculated from all dives longer than $30 \mathrm{~s}$.

common (55\%). Clyde's longest dive lasted 9-10 min. Clarke (1986) reported that Risso's dolphins can dive for as long as $30 \mathrm{~min}$, but no specific source for this value was cited. Clyde's $44.6 \%$ hematocrit immediately before release indicates a lack of capacity for regularly engaging in long dives.

Time-at-depth data were obtained for 22 6-h blocks (Fig. 5). Clyde spent more than $99 \%$ of his time within $50 \mathrm{~m}$ of the surface, in the top $10 \%$ of the water column. He was $10-50 \mathrm{~m}$ below the surface for $36 \%-51 \%$ of his time and within $1 \mathrm{~m}$ of the surface for $18 \%-33 \%$ of his time, depending on the time period. Diurnal patterns in time-at-depth were not evident.

Clyde likely survived beyond the end of the tracking period. His record of good health during his final $2.5 \mathrm{mo}$ at the rehabilitation facility bolstered the probability of his survival in the wild. There was no evidence from remote sensing to suggest that signals ceased because Clyde died. Most of the satellite fixes for Clyde, especially those at the end of the track, were in or near habitats where Risso's dolphins have been seen frequently. No changes in travel rates, dive durations, or dive depths were observed that might indicate declining health. The apparent survival of Clyde for at least $23 \mathrm{~d}$ postrelease suggests that the rehabilitation was successful.

One of the strongest justifications for engaging in the difficult and expensive process of cetacean rehabilitation is to advance our understanding of wild populations (Moore et al. 2007). The follow-up monitoring of Clyde provided a unique opportunity to learn about a species that is difficult to study in the wild, albeit with the 


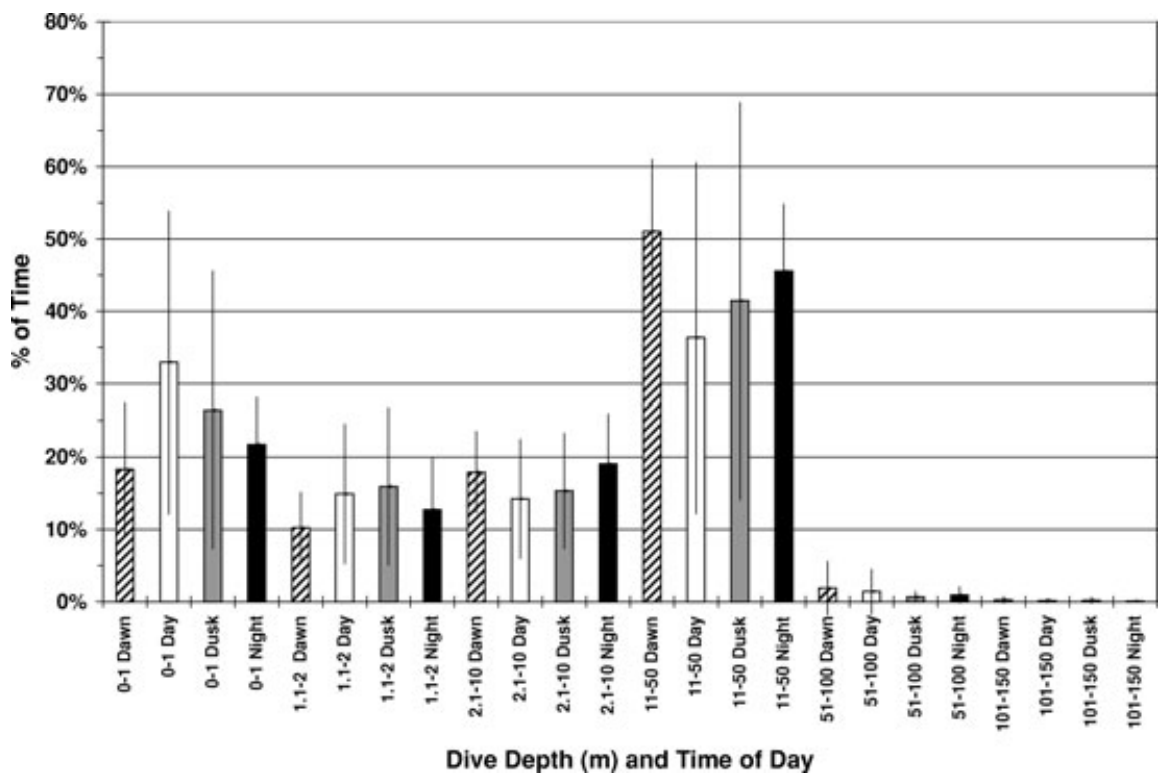

Figure 5. Average percent of time spent within specified depth ranges during the four time-of-day periods, with standard deviations. Clyde spent very little time below $50 \mathrm{~m}$, regardless of time of day.

caveat that potential impacts from his stranding and rehabilitation on his postrelease behavior are difficult to assess. Most, but not all, of his movements were through areas where water depth, sea floor relief, and sea surface temperature were consistent with previous descriptions for Risso's dolphins. Clyde's movements from the Gulf of Mexico to the Atlantic Ocean have potentially important management implications, given that most delphinid stock descriptions currently limit stocks to one basin or the other (Waring et al. 2006). Similar questions regarding delphinid stock definitions were raised by the movements of rehabilitated bottlenose dolphins released in the Gulf of Mexico and tracked into the Atlantic Ocean (Wells et al. 1999). Clyde's dive records, the first for this species, suggest that Risso's dolphins do not engage in frequent deep dives, contrary to some previous descriptions. Opportunities to study offshore delphinids are rare, due in large part to the expense of conducting research at sea. In the absence of dedicated studies of these species, we will need to continue to rely on the opportunistic compilation of records from a variety of sources, such as rehabilitated individuals, to incrementally increase our understanding of these animals.

\section{ACKNOWLEDGMENTS}

Without the efforts of Denise Boyd and Mindy Peterson, along with Florida Fish and Wildlife Conservation Commission (FWC) Law Enforcement agents, the first responders to the mass stranding, Clyde would not have survived to undergo rehabilitation. The dedicated 
efforts of the volunteers of Mote Marine Laboratory's Dolphin and Whale Hospital helped to get Clyde to the point of release. We are tremendously indebted to Tom Sansone and Cathy Unruh of the vessel Tomcat for carrying Clyde and our crew far out to sea for the release, and doing it in a style to which we would like to become accustomed. Leigh Klatsky of Dolphin Quest helped tremendously with data filtering and advice on interpreting tag data.

\section{Literature Cited}

BAIRD, R. W. 2002. Risso's dolphin Grampus griseus. Pages 1037-1039 in W. F. Perrin, B. Würsig and J. G. M. Thewissen, eds. Encyclopedia of marine mammals. Academic Press, San Diego, CA.

BAumgartner, M. F. 1997. The distribution of Risso's Dolphin (Grampus griseus) with respect to the physiography of the northern Gulf of Mexico. Marine Mammal Science 13:614638.

Clarke, M. R. 1986. Cephalopods in the diet of odontocetes. Pages 281-321 in M. M. Bryden and R. Harrison, eds. Research on dolphins. Clarendon Press, Oxford, UK.

Clarke, M. R., AND P. L. PAsCoe. 1985. The stomach contents of a Risso's dolphin (Grampus griseus) stranded at Thurlesone, South Devon. Journal of the Marine Biological Association of the U.K. 65:663-665.

Davis, R. W., G. S. Fargion, N. May, T. D. Leming, M. Baumgartner, W. E. Evans, L. J. HANSEN AND K. MuluIN. 1998. Physical habitat of cetaceans along the continental slope in the north-central and western Gulf of Mexico. Marine Mammal Science 14:490-507.

Douglas, D. 2006. Documentation: Douglas-Argos filter algorithm Version 7.02. USGS Alaska Science Center, Juneau, AK. Available at http://alaska.usgs.gov/science/ biology/spatial/.

KLAtsky, L. J., R. S. Wells AND J. C. Sweeney. 2007. Offshore bottlenose dolphins (Tursiops truncatus): Movement and dive behavior near the Bermuda Pedestal. Journal of Mammalogy 88:59-66.

Kruse, S., D. K. Caldwell and M. C. Caldwell. 1999. Risso's dolphin Grampus griseus (G. Cuvier, 1812). Pages 183-212 in S. H. Ridgway and R. Harrison, eds. Handbook of marine mammals. Volume 6. The second book of dolphins and the porpoises. Academic Press, San Diego, CA.

MAZE-Foley, K., AND K. D. Muluin. 2006. Cetaceans of the oceanic northern Gulf of Mexico: Distributions, group sizes, and interspecific associations. Journal of Cetacean Research and Management 8:203-213.

Moore, M. M, G. Early, K. Touhey, S. Barco, F. Gulland and R. Wells. 2007. Rehabilitation of marine mammals in the United States: Risks and benefits. Marine Mammal Science 23:731-750.

Mullin, K. D., AND G. L. Fulling. 2004. Abundance of cetaceans in the oceanic northern Gulf of Mexico. Marine Mammal Science 20:787-807.

Mullin, K. D., W. Hoggard, C. L. Roden, R. R. Lohoefener, C. M. Rogers and B. TAGGART. 1994. Cetaceans on the upper continental slope in the north-central Gulf of Mexico. Fishery Bulletin 92:773-786.

Mullin, K. D., W. Hoggard and L. J. Hansen. 2004. Abundance and seasonal occurrence of cetaceans in outer continental shelf and slope waters of the north-central and northwestern Gulf of Mexico. Gulf of Mexico Science 22:62-73.

NORRIS, K. S., AND T. P. DOHL. 1980. The structure and function of cetacean schools. Pages 211-261 in L. M. Herman, ed. Cetacean behavior: Mechanisms and functions. Wiley, New York.

Smith, W. H. F., AND D. T. SANDwell. 1997. Global sea floor topography from satellite altimetry and ship depth soundings. Science 277:1957-1962. 
Waring, G. T., E. Josephson, C. P. Fairfield and K. Maze-foley, eds. 2006. U.S. Atlantic and Gulf of Mexico marine mammal stock assessments-2005. NOAA Technical Memorandum NMFS-NE-194. 346 pp.

WeLLS, R. S. 2002. Identification methods. Pages 601-608 in W. F. Perrin, B. Würsig and J. G. M. Thewissen, eds. Encyclopedia of marine mammals. Academic Press, San Diego, CA.

Wells, R. S., H. L. Rhinehart, P. Cunningham, J. Whaley, M. Baran, C. Koberna and D. P. CostA. 1999. Long-distance offshore movements of bottlenose dolphins. Marine Mammal Science 15:1098-1114.

Wells, R. S., G. A. Early, J. G. Gannon, R. G. Lingenfelser and P. Sweeney. 2008. Tagging and tracking of rough-toothed dolphins (Steno bredanensis) from the March 2005 mass stranding in the Florida Keys. NOAA Technical Memorandum NMFS-SEFSC-574. $44 \mathrm{pp}$.

Received: 21 February 2008

Accepted: 7 August 2008 